\title{
Encephalopathy due to prosaposin deficiency
}

INSERM

\section{Source}

INSERM. (1999). Orphanet: an online rare disease and orphan drug data base.

Encephalopathy due to prosaposin deficiency. ORPHA:139406

Encephalopathy due to prosaposin deficiency is a lysosomal storage disease belong ing to the group of sphingolipidoses. 